\title{
ENVIRONMENTAL ANALYSES OF THE PARASITIC PROFILE FOUND IN THE SANDY SOIL FROM THE SANTOS MUNICIPALITY BEACHES, SP, BRAZIL
}

Silvana ROCHA(1), Rosa Maria Ferreiro PINTO(1), Aline Petrollini FLORIANO(1), Lais Helena TEIXEIRA(1), Bianca BASSILI(2), Araceles MARTINEZ(2), Sergio Olavo Pinto da COSTA(1) \& Marcos Montani CASEIRO(1)

\begin{abstract}
SUMMARY
The environmental contamination by geohelminths represents a world public health problem and has been well documented by several authors. However, few papers describe the presence of such contamination in saline soils of coastal beaches. A study was performed on the beaches of the municipality of Santos in the period between May 2004 to April 2005 with the aim of determining the degree of contamination, and the correlation between contamination level and seasonal conditions and characteristics of the environment. Of the 2,520 samples analyzed, $18.2 \%$ (458) were contaminated, $32.3 \%$ (148) of which were localized in children's recreational areas (playgrounds).

The parasite profile found in the analyzed samples indicated the presence of several zoonotic parasites: Ancylostoma larvae (82.5\%), Toxocara sp. eggs (59.4\%), Ancylostomidae-like eggs (37.1\%), coccid oocysts (13.5\%), Trichostrongylus sp. eggs and larvae, Ascaris lumbricoides eggs, (11.6\%), Entamoeba sp. cysts (10.0\%), Strongyloides sp. (4.8\%), several free nematoids and some non-identified parasitic structures (3.3\%). It was established that the highest frequency of parasitic structures occurred in the months between May and October 2004, and from February to March 2005. An increase in the diversity of parasitic forms was documented in the months between February to December 2004 and from January to April 2005, these periods having the highest rainfall.
\end{abstract}

KEYWORDS: Larva migrans; Toxocariasis; Sandy soil; Beaches.

\section{INTRODUCTION}

Geohelminths are parasites that require soil to fulfill a step of their developmental cycle, allowing eggs to develop into embryos and viable larvae until contact with a new host. The infective forms of those geohelminths (eggs or larvae) are found more often in sandy soil, contaminated with human or animal feces ${ }^{2}$.

According to the OPAS $2002^{13}$ report, it is estimated that two billion people in the world are infected by some form of parasite acquired through the contact with the soil, 800 million of which are infected children (40\%), with about 20-30\% occurring in Latin America populations ${ }^{13}$.

The increasing urbanization observed in Brazilian cities results in a concentration of people at the periphery of the big cities, generally in areas with precarious sanitary infrastructure, causing environmental contamination through sewage, which is further distributed by rain, birds or insects.

The canine and feline populations that circulate in Brazilian city streets may access public recreational places and, when defecating contaminate the soil with several types of parasites resulting in zoonotic transmission. This contamination has become an important public health problem, particularly in the tropical and subtropical regions of developing countries.

Sandy soils represent an important source of human infection by parasites, due to their geological characteristics, being formed by sand particles with diameters ranging from 0.02 to $2 \mathrm{~mm}$, and with the ability to retain water between the spaces of soil particles. Helminth larval stages are notably aquatic, and a high humidity of the soil is essential for their survival. In addition, the rain pattern, the rate of evaporation and the amount of sun to which the infected soil is exposed, strongly influences both the development of eggs into embryos and in the viable larva stages. Ideal conditions for rapid parasite development are provided by frequent rain throughout the year in places with sandy soil which are not directly exposed to sun and are protected from intense evaporation. The optimal temperatures for parasite development in soil ranges between 23 and $30^{\circ} \mathrm{C}$, with an upper limit of $40^{\circ} \mathrm{C}$ at the high end; at the low end development becomes slower at temperatures below $17^{\circ} \mathrm{C}$ and stops below $10^{\circ} \mathrm{C}^{21}$.

However, the eggs of Ascaris develop well in white clay soils in which

1) Collective Health Course. Catholic University of Santos. Sao Paulo State. Brazil.

(2) Biological Science. Catholic University of Santos, Sao Paulo. Brazil.

Correspondence to: Marcos Montani Caseiro; Rua Hercules Florence s/n, 11070-905 Santos, SP, Brasil. E-mail: mcaseiro@uol.com.br 
ROCHA, S.; PINTO, R.M.F.; FLORIANO, A.P.; TEIXEIRA, L.H.; BASSILI, B.; MARTINEZ, A.; COSTA, S.O.P. \& CASEIRO, M.M. - Environmental analyses of the parasitic profile found in the sandy soil from the Santos municipality beaches, SP, Brazil. Rev. Inst. Med. Trop. Sao Paulo, 53(5): 277-81, 2011.

rain water accumulates just under the surface. In temperatures between $15^{\circ} \mathrm{C}$ and $35^{\circ} \mathrm{C}$ these eggs exhibit appropriate embryonic development, but are blocked by temperatures below $15^{\circ} \mathrm{C}$, and completely disintegrate in temperatures above $35^{\circ} \mathrm{C}^{1}$.

Recently, several studies have analyzed beach and/or sand in bathing areas, but the most relevant indicator is still the bathing quality of the waters regarding total and fecal coliform contamination. However, some researchers ${ }^{3,4,15,17}$ have showed interest in evaluating the sanitary quality of the sand from beaches with pioneer work in Brazil resulting in analysis of coastal areas. In those studies, several species of parasites pathogenic to humans, such as Strongyloides stercoralis, Toxocara sp, Ascaris lumbricoides, and several protozoan were found, characterizing the unhealthy conditions of these places and demonstrating the possibility of contamination both by human and animal defecation, that can be freely distributed further by dogs and/or cats that freely circulate on the beach.

These studies have largely contributed to pointing out the problem of infection of bathing individuals by parasite eggs and larvae dispersed on the beaches, and address an appeal from the RESOLUTION No. 274 (November 29 $9^{\text {th }}, 2000$ - Article No. 8) ${ }^{20}$ from the CONAMA (The National Organization for the Environment), therefore contributing as a source of information for the Public Health authorities, and helping in the planning of the control actions.

The aim of this work is to evaluate the parasite profile of the sandy soil from the beaches of the municipality of Santos, located in the State of Sao Paulo, Brazil.

\section{MATERIAL AND METHODS}

Collecting of samples: Twelve collections were performed on each of the seven beaches of Santos, in the period between May 2004 and April 2005 at monthly intervals, always starting at 9:00 a.m. The areas studied were 20 meters wide located between the side-walk and the high tide mark on the beach in areas where the majority of the children's playgrounds, food tents and sports areas are located. Each beach was divided into four rectangular areas $(20 \mathrm{~m} \times 100 \mathrm{~m})$, within which five collection locations were randomly selected and their location plotted by GPS (Fig. 1); at each location two $100 \mathrm{~g}$ aliquots of sand were collected at a depth of $10 \mathrm{~cm}$. In parallel, measurements of soil and air temperatures, percentage humidity and exposure to light were performed.

Sample identification and analysis: After numerical identification according to the beach and sampling location, samples were packed and transported in plastic bags to the Parasitology Laboratory of the Catholic University of Santos, where they were analyzed: one aliquot by a method for screening for Nematoid larvae of Rugai, Matos, Brizolla ${ }^{12}$ modified by Picanço ${ }^{14}$, which increases the time of contact with water for two hours; the other according to the spontaneous sedimentation method of Lutz, Hoffman, Pons \& Janer in association with floatation in a dense solution of zinc sulfate, density 1,180 of FAUST et al., to search for helminthes eggs or protozoan oocysts, adapted for research in sandy soil ${ }^{12}$. In this analyses, the $100 \mathrm{~g}$ of sand had been previously washed in tap water, filtered and drained off in a nylon sieve (net with $\cong 0.15 \mathrm{~mm}$ openings) with a diameter of $10 \mathrm{~cm}$ containing a piece of lint folded four times to form a sedimentation vessel with a $\sim 250 \mathrm{~mL}$ capacity. The sediments

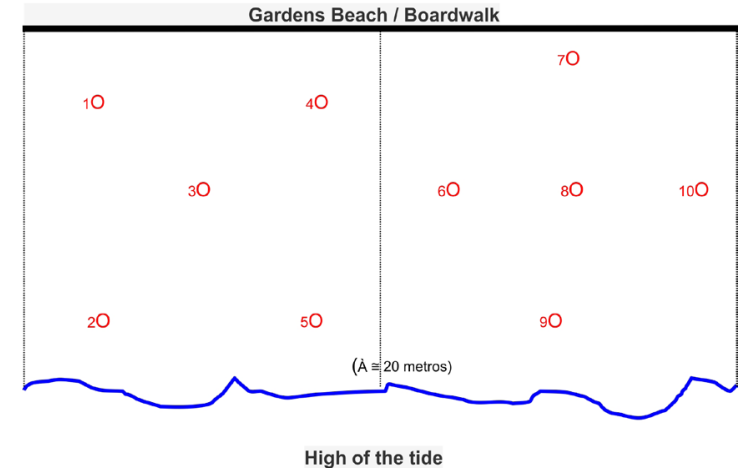

Fig. 1 - Scheme of the distribution of collection points in the extension of sand from the beaches of the municipality of Santos, plotted by GPS.

were allowed to rest for approximately 12 hours. Afterwards, several aliquots of the $2 \mathrm{~cm}$ of superficial layer were collected from the sand sediment in the bottom of the sedimentation vessel using a straw, then transferred to a glass slide and submitted to microscopic screening for parasite structures.

The sediment remaining in the bottom of the sedimentation vessel that had been processed using the floatation technique, discarding the supernatant and resuspending the two superficial centimeters of sand deposited in the bottom of the sedimentation vessel, was submitted to brief centrifugation. The deposit formed in the bottom of the centrifuge tube was diluted in zinc sulfate solution $(\mathrm{d}=1,180)$, and then submitted to new centrifugation at 2,000 rpm for five minutes.

To identify the found parasitic structures, we used the following parameters recommended by the World Health Organization (WHO): protocols prepared by ASH, ORIHEL and SAVIOLI, WHO ${ }^{18}$, translated by Pasternak in 2000; parameters proposed by DE CARLI, 2000' veterinary parameters proposed by URQUHART et al., 199824; comparative keys for identification of Nematoid larvae stained with 5\% lugol solution proposed by PESSOA \& MARTINS, $1978^{19}$.

Since the period between collection and analysis of the samples was less than $72 \mathrm{~h}$, no preservative was used on the samples.

\section{RESULTS}

Two thousand five hundred and twenty samples were collected from which $18.2 \%$ (458) contained parasite structures, $32.3 \%$ (148) of which were localized in children's recreational areas.

The monthly averages of parasite structures found are depicted in Fig.2, showing a significant increase in the months of May 2004, October 2004, February 2005 and March 2005.

The Correlation between the average temperatures of the soil with the monthly frequencies of parasites, evaluated from May 2004 to April 2005; the relation between the measured monthly average temperatures of the soil with the parasitary structures found is shown, and the variation registered was between $20^{\circ} \mathrm{C}$ to $24{ }^{\circ} \mathrm{C}$, making it possible that parasite forms occur in all investigated months (Fig. 3). The same features were observed in the sand from recreational areas. 


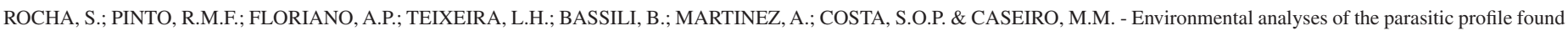
in the sandy soil from the Santos municipality beaches, SP, Brazil. Rev. Inst. Med. Trop. Sao Paulo, 53(5): 277-81, 2011.

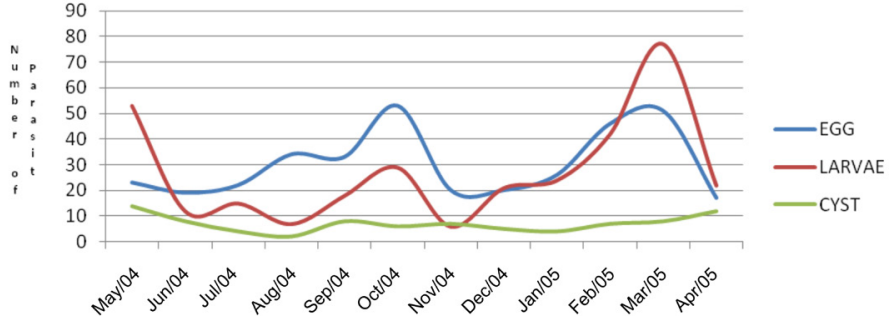

Fig. 2 - Monthly total of parasite structures found in samples collected from May 2004 to April 2005

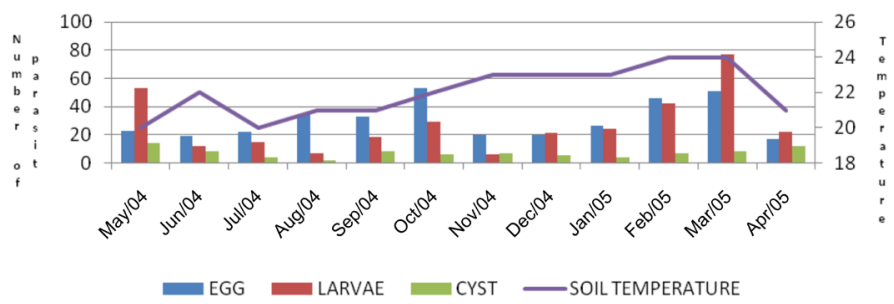

Fig. 3 - Correlation between the average temperatures of the soil with the monthly frequencies of parasites, evaluated from May 2004 to April 2005.

Investigation of the relationship of the monthly rainfall $(\mathrm{mm})$ and the frequency of parasite structures found in the sand from the municipality of Santos beaches, collected from May 2004 to April 2005 (Fig. 4). The rainfall data was measured by SOMAR meteorology. The comparison between rainfall and frequency of parasite structures clearly showed an increase in helminth eggs and larvae in the months following the heavy rainfall, indicating a relationship between environmental contamination and the rain season.

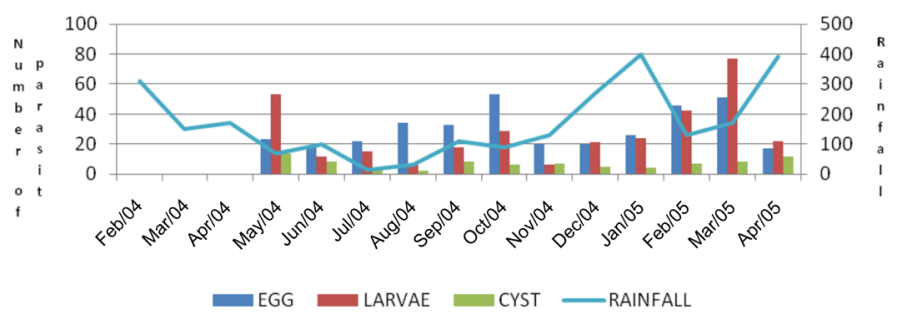

Fig. 4 - Investigation of the relationship of the monthly rainfall $(\mathrm{mm})$ and the frequency of parasite structures found in the sand from the municipality of Santos beaches, collected from May 2004 to April 2005.

\section{DISCUSSION}

Contamination of the sandy soil from Santos beaches by several parasites have been demonstrated indicating the possibility of zoonotic occurrence of human infection by enteroparasites through the soil.

In this regard, it should be noted that the city of Santos had an epidemic of cutaneous larva migrans syndrome among regular users of the beach, which eventually led to the inclusion of the disease in the list of those diseases requiring compulsory notification to the municipality $\left(\right.$ CASEIRO, 1996) ${ }^{7}$.
Table 1

Univariate analyses of the helminthes frequency found in the sand from the Santos municipality beaches, collected from May 2004 to April 2005

\begin{tabular}{lccccc}
\hline Beaches & $\begin{array}{c}\text { Eggs } / \\
\text { Larvae }\end{array}$ & $\mathbf{\%}$ & $\mathbf{N}$ & OR $^{*}$ & IC $^{* *}(\mathbf{9 5 \%})$ \\
\hline Emissário & 154 & $\mathbf{5 1 . 3}$ & 300 & $\mathbf{8 . 0}$ & $\mathbf{4 . 2} \mathbf{- 1 5 . 3}$ \\
José Menino & 76 & $\mathbf{4 2 . 2}$ & 180 & $\mathbf{5 . 5}$ & $\mathbf{2 . 8} \mathbf{- 1 0 . 9}$ \\
Gonzaga & 187 & $\mathbf{5 2}$ & 360 & $\mathbf{8 . 2}$ & $\mathbf{4 . 3} \mathbf{- 1 5 . 5}$ \\
Boqueirão & 137 & $\mathbf{4 5 . 6}$ & 300 & $\mathbf{6 . 4}$ & $\mathbf{3 . 4} \mathbf{- 1 2 . 2}$ \\
Embaré & 86 & $\mathbf{3 5 . 9}$ & 240 & $\mathbf{4 . 2}$ & $\mathbf{2 . 2} \mathbf{- 8 . 2}$ \\
Aparecida & 45 & 15 & 300 & 1.3 & $0.7-2.7$ \\
Ponta da Praia & 14 & 11.7 & 120 & - & - \\
\hline Total & 699 & 38.9 & 1800 & - & - \\
\hline
\end{tabular}

Source: Samples analyzed in the Parasitological Laboratory from Unisantos. $* \mathrm{OR}=$ Odds ratio $; *$ IC $=$ Confidence Interval $; p<0.05$.

In the beaches of Santos, the "black tongues" (sewage) were not involved, although it is common on several beaches of our coast, where it contributes to the contamination of the local sandy soil ${ }^{3}$. In the municipality of Santos, the sewage is treated by SABESP (Basic Sanitation Company of the State of São Paulo) and released $2.8 \mathrm{~km}$ from the coast (Submarine Outfall), which helps the bathing conditions. However, the human and animal fecal deposits left in the streets of the city are washed into the drainage channels by the rain, which has a strong impact on the sanitary conditions of local water and coastal sand. This fact may explain the high index of helminth eggs and larvae found in the analyzed samples, with an important indicator being the detection of Ascaris lumbricoides in $11.6 \%$ of the analyses.

Similarly in two works carried out on the beaches of Rio de Janeiro by NABUCO et al. in $1999^{17}$ and SILVA \& PASTURA, $2000^{23}$, the sand strip studied was located between the sidewalk and the high-tide mark, over an approximated width of 20 meters, suggesting that the parasites are sensitive to high salt concentrations. This fact was corroborated in the samples collected close to the water (200), where no parasite structures were found. On the beaches of Santos, this sand strip is not constantly washed by sea water, and where a large variety of leisure activities, such as sport courts and socializing areas are concentrated, in addition to large numbers of carts of food vendors. In this area child recreational areas with playgrounds with wooden equipment are also located, and where there is a large concentration of people between $8 \mathrm{a} . \mathrm{m}$. and $10 \mathrm{a} . \mathrm{m}$. or at the end of the day, and where people remain for long periods of time.

We verified that the samples with the largest amounts of parasite structures were collected between May and October 2004, and February and March 2005, although the distribution of the structures observed was diversified, with viable parasites occurring in every month of collection. This can be explained by the data analyses regarding soil temperature, which was shown to be stable during the whole collecting period, with a yearly average at around $22{ }^{\circ} \mathrm{C}$, which favors both the embryo development of helminthes and the viability and development of nematoid larvae. Another contributing factor is the variation in rainfall with higher concentration of rains between February and December 2004, and January 


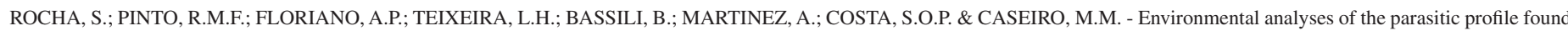
in the sandy soil from the Santos municipality beaches, SP, Brazil. Rev. Inst. Med. Trop. Sao Paulo, 53(5): 277-81, 2011.

and April 2005, being followed by increases in the number of parasites.

It is important to mention the methodology used by MILANO \& OSCHEROV ${ }^{16}$ on the beaches of the City of Corrientes, Argentina, which are washed by the Paraná River. For that, they used eight meter quadrants in which the collection sites were located, facilitating a random sampling.

The methodology used by CÁCERES et al. ${ }^{4}$ in their study of the "Praia dos Milionários" (Millionaires' Beach) at Ilhéus, Bahia, the distribution of the sampling sites was a random zigzag between the tents on the sidewalk and the sea. The study of these beaches revealed environmental differences to those from Santos, which may account for the lower parasite contamination encountered.

Many different solutions $\mathrm{s}^{4,5,6,8,9,11,15,16}$ have been proposed for searching for helminths' eggs in soil, but rarely for their detection in the sand of marine beaches.

An important publication from SILVA et al. ${ }^{22}$ in 1991 evaluated the experimental contamination of beach sand by enteroparasites and the search for helminth eggs, aiming to study the suitability of methods traditionally used for examination of the soil of sandy beaches, by comparison to other solutions not yet tested for this purpose. The research showed that the following solutions are the most efficient: Sodium bicromate; Sodium chloride; Sodium hydroxide and zinc sulfate, instead of Sodium hypoclorite, which alters or destroy the eggs from several species of helminthes, impairing their identification ${ }^{12,14}$.

In the experiments described here, several solutions proposed in the aforementioned paper were tested, and the most suitable considering the aims of the research was zinc sulfate, used as a saturated solution with a density of 1,180. In addition, we included sedimentation and floating methods, and the combination permitted a larger number of different parasites to be found.

The parasite profile found in the analyzed samples indicated the presence of several zoonotic parasites: Ancylostoma larvae (82.5\%), Toxocara sp. eggs (59.4\%), Ancylostomidae-like eggs (37.1\%), coccids oocysts (13.5\%), Trichostrongylus sp. eggs and larvae, Ascaris lumbricoides eggs, (11.6\%), Entamoeba sp. cysts (10.0\%), Strongyloides sp. $(4.8 \%)$, several free Nematodes and some non-identified parasitary structures $(3.3 \%)$.

The evaluation of the sand contamination by parasites of zoonotic relevance performed on the beaches of Corrientes, Argentina, by MILANO \& OSCHEROV $^{16}$ in 2002, indicated a positive rate of $32.7 \%$, with a $100 \%$ prevalence for ancylostomids and $0.3 \%$ for Toxocara sp; parasite contamination was considered present when at least one positive sample was found for the parasites mentioned above. This data is not in agreement with ours from the beaches of Santos; however the beaches of Corrients are less salty.

The study performed by LAGGAGIO et al..$^{15}$ on three beaches from Guaiba municipality, Rio Grande do Sul showed yet a different parasite profile once again, with the presence of Taenia sp eggs (3.48\%), Giardia sp cysts $(9.0 \%)$, and a low prevalence of ancylostomids.

The analyses performed on the beaches of Guanabara in Rio de
Janeiro, in April 2003 and March 2004, by the Commision of Environment Protection (BORDINHÃO \& COSTA) ${ }^{3}$, showed a profile of: Enterobius vermicularis (30\%), Ascaris lumbricoides (20\%), Giardia lamblia cysts (16\%), Entamoeba histolytica cysts (16\%), Strongyloides stercoralis (10\%), Ancylostomids (5\%), Trichuris trichiura (5\%), which is quite different from Santos and can be attributed to the sewage "tongues" formed because of the rains, illegal connections with river water and the lack of sanitary services in the adjacent communities.

In recent work realized in "Praia Grande" municipality by CASTRO et al. $(2005)^{9}$, in which the contamination of areas of the sea border by ancylostomid eggs and Toxocara, and samples of dog feces were evaluated, the results showed a total of $45.9 \%$ positivity for ancylostomids and $1.2 \%$ for Toxocara sp, suggesting a possible contamination of the sand beach with fecal deposits, particularly due to rain.

A study realized by CÁCERES et al. ${ }^{4}$, on the South beach of Ilhéus, Bahia, evaluated the presence of nematoid larvae in sandy soil at different depths, and showed the presence of Strongyloides stercoralis (41.66\%) and Ancylostomidae (58.33\%) larvae, with no significant differences related to depth of collected sample, which is explained by the behavior of the rhabditoids and filarioids larvae that present positive and negative geotropism, respectively.

An aspect that deserves attention is the high frequency of parasites found in the sand from recreational areas where a very large population of children spends several hours a day in close contact with sandy soil (Fig. 5).

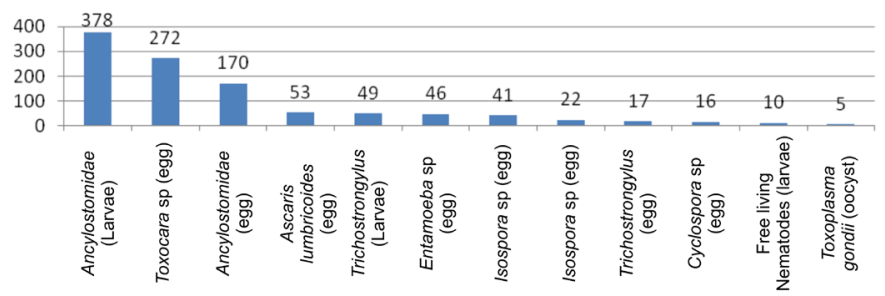

Fig. 5 - Parasite frequencies found in the sand from the municipality of Santos beaches, collected from May 2004 to April 2005.

The region of "Ponta da Praia" was used as reference because it presents a narrower width of sand than other beaches, so that during high tides a large portion of this area is under sea water, thereby increasing local salinity and impairing the parasitic development and viability.

The presented results contrast with the lack of epidemiological references to cutaneous and visceral larva migrans infection in the Santos Municipality. It is likely that the majority of infections by Toxocara are either asymptomatic or oligosymptomatic, spontaneously progressing to cure. The same happens with the skin infestations by ancylostomids larvae, where treatment by home methods usually progresses to a cure.

The results indicate the presence of different parasites that are zoonotic agents in every beach sampled, and where the environment allows long term survival of parasitic forms. Furthermore, the presence of Ascaris lumbricoides eggs in several samples constitutes an important biological marker of human fecal contamination and gives warning for the possible transmission of other agents such as enterovirus, hepatitis A virus and enterobacterias to other humans. 
ROCHA, S.; PINTO, R.M.F.; FLORIANO, A.P.; TEIXEIRA, L.H.; BASSILI, B.; MARTINEZ, A.; COSTA, S.O.P. \& CASEIRO, M.M. - Environmental analyses of the parasitic profile found in the sandy soil from the Santos municipality beaches, SP, Brazil. Rev. Inst. Med. Trop. Sao Paulo, 53(5): 277-81, 2011.

The results presented here are a major cause for concern, since they show the high level of parasitic contamination of the sandy beaches of the Santos coast. These areas constitute the main options of leisure for both adults and children, and point to the need of proper signaling and information regarding public health hazards, in order to avoid undesired consequences.

Sanitary and environmental education must become a requirement for the human users of the beaches, including the presence of domestic animals in these locations and the need to remove their fecal deposits and to dispose of them correctly.

\section{RESUMO}

\section{Análise ambiental do perfil de estruturas parasitárias encontradas no solo arenoso das praias do município de Santos, SP, Brasil}

A contaminação ambiental por geohelmintos representa um problema mundial de saúde pública e tem sido bem documentada por diversos autores. No entanto, poucos trabalhos descrevem a presença de contaminação em solos salinos de praias litorâneas. Este estudo foi realizado nas praias do município de Santos no período entre maio de 2004 a abril de 2005 com o objetivo de determinar o grau de contaminação, e possíveis correlações entre sazonalidade e características ambientais. Das 2.520 amostras analisadas, 18,2\% (458) estavam contaminadas, $32,3 \%$ (148) das quais foram localizadas em areas de lazer das crianças(playgrounds).

O perfil parasitário encontrado nas amostras analisadas indicaram a presença de vários parasitos com potencial zoonótico: larvas de Ancylostoma (82,5\%), ovos de Toxocara sp (59,4\%), ovos semelhantes aos de Ancilostomídeos (37,1\%), oocistos de coccídeos (13,5\%), ovos de Trichostrongylus sp., ovos de Ascaris lumbricoides, $(11,6 \%)$, cistos de Entamoeba sp. (10,0\%), Strongyloides sp. (4,8\%), vários nematóides de vida livre e algumas estruturas parasitárias não identificadas que podem corresponder a um parasita $(3,3 \%)$. Foi estabelecido que a maior frequência de estruturas parasitárias ocorreu nos meses entre maio e outubro de 2004, e de fevereiro a março de 2005. Um aumento na diversidade de formas parasitárias foi documentado nos meses entre fevereiro a dezembro de 2004 e de janeiro a abril de 2005, esses períodos com a maior pluviosidade.

\section{REFERENCES}

1. Abe-Jacob CM, Pastorino AC, Peres BA, Mello EO, Okay Y, Oselka GW. Clinical and laboratorial features of visceral toxocariasis in infancy. Rev Inst Med Trop Sao Paulo. 1994;36:19-26.

2. Acunã A, Calegari L, Curto S, Lindner C, Rosa R, Salvatella R, et al. Helmintiasis intestinales. Manejo de las geohelmintiasis. Montevideo: Organización Panamericana de la Salud; 2003.

3. Bordinhão P, Costa LM. Areia contaminada das praias da Guanabara. Bol Comissão Meio Ambiente Assembléia Legislativa Est Rio de Janeiro. 2006;(1).

4. Cáceres APSG, Gonçalves FA, Cazoria IM, Carvalho SMS. Contaminação do solo por helmintos de importância médica na praia do sul (Milionários), Ilhéus-BA. Rev Bras Anal Clín. 2005;37:53-5.

5. Campos DMB, Leão DA, Isac E, Calil F. Pesquisa de ovos de Toxocara sp. em localidades públicas da cidade de Goiânia - Goiás. 1. Comparação de métodos de exame. Rev Patol Trop. 1987;16:7-11.
6. Carvalho SM, Gonçalves FA, Campos Filho PC, Guimarães EM, Cáceres AP, Souza YB, et al. Adaptação do método de Rugai e colaboradores para análises de parasitas do solo. Rev Soc Bras Med Trop. 2005;38:270-1.

7. Caseiro MM. Síndrome de larva migrans visceral causada por larvas de Toxocara canis (Werner,1782 e Stiles,1905), no Município de Santos, São Paulo, 1994-1996. [Dissertação]. São Paulo: Faculdade de Medicina da Universidade de São Paulo; 1997.

8. Castillo D, Paredes C, Zañartu C, Castillo G, Mercado R, Muñoz V, et al. Contaminación ambiental por huevos de Toxocara sp. en algunas plazas y parques públicos de Santiago de Chile, 1999. Bol Chil Parasitol. 2000;55(3-4):86-91.

9. Castro JM, Santos, SV, Monteiro NA. Contaminação de canteiros da orla marítima do Município de Praia Grande, São Paulo, por ovos de Ancylostoma e Toxocara em fezes de cães. Rev Soc Bras Med Trop. 2005;38:199-201.

10. Chieffi PP, Amato Neto V. Vermes, verminoses e a saúde pública. Cienc Cult. 2003;55:413.

11. Costa-Cruz JM; Nunes RS, Buso AG. Presença de ovos de Toxocara spp em praças públicas da cidade de Uberlândia, Minas Gerais, Brasil. Rev Inst Med Trop Sao Paulo. 1994;36:39-42.

12. De Carli GA. Parasitologia clínica: seleção de métodos e técnicas de laboratório para o diagnóstico das parasitoses humanas. São Paulo: Atheneu, 2000.

13. Ehrenberg J. Por um continente livre de verminoses. Washington: Organização PanAmericana da Saúde; 2002.

14. Freitas CE, Litton E. Exames parasitológicos. $3^{\text {a. }}$ ed. Fortaleza: Brasil Tropical; 1999.

15. Laggagio VRA, Jorge LL, Oliveira V, Flores ML, Silva JH. Presença de endoparasitas em três praias do Município de Guaíba-RS/Brasil, 2001. [cited 2004 Oct 22]. Available from: <http://www.redevet.com.br/artigos/praias.html>.

16. Milano AMF, Oscherov EB. Contaminación por parásitos caninos de importancia zoonótica en playas de la ciudad de Corrientes, Argentina. Parasitol Latinoam. 2002;57:119-23.

17. Nabuco BFP, Pandholpho VC, Santos JA. Ocorrência de ovos de helmintos, cistos e oocistos de protozoários na areia da praia de Copacabana. Rio de janeiro, 1999. [Cited: 2004 Sept 23]. Available from: <http://www.crmvrj.com.br/cong/ ovos.htm>.

18. Organização Mundial da Saúde. Pranchas para o diagnóstico de parasitas intestinais; Ash R, Orihel TC, Savioli L. São Paulo: OMS; Editora Santos; 2000.

19. Pessoa SB, Martins AV. Parasitologia médica. 10 ed. Rio de Janeiro: Guanabara Koogan; 1978.

20. Resolução CONAMA nº. 274 de 29 de novembro de 2000. Conselho Nacional do Meio Ambiente. Revisão dos critérios de Balneabilidade em Águas Costeiras.

21. Rey L. Parasitologia: parasitos e doenças parasitárias do homem nas Américas e na África $3^{\mathrm{a}}$ ed. Rio de Janeiro: Guanabara Koogan; 2001.

22. Silva JP, Marzochi MCA, Santos ECL. Avaliação da contaminação experimental de areias de praias por enteroparasitas: pesquisa de ovos de helmintos. Cad Saúde Pública. 1991;7:90-9.

23. Silva CAMC, Pastura, CP. Qualidade sanitária da areia das praias do Município do Rio de Janeiro. In: $27^{\circ}$ Congreso Interamericano de Ingeniería Sanitária y Ambiental, 3-8 Diciembre 2000, Porto Alegre, Brasil.

24. Urquhart GM, Armour J, Duncan JL, Dunn AM, Jennings FW. Parasitologia veterinária. $2^{\text {a }}$ ed. Rio de Janeiro: Guanabara Koogan; 1998.

Received: 10 September 2009

Accepted: 6 September 201 


\section{LIBRARY OF THE SÃO PAULO INSTITUTE OF TROPICAL MEDICINE}

Website: www.imt.usp.br/portal

Address: Biblioteca do Instituto de Medicina Tropical de São Paulo da Universidade de São Paulo Av. Dr. Enéas de Carvalho Aguiar, 470. Prédio 1 - Andar térreo.

05403-000 São Paulo, SP, Brazil.

Telephone: 5511 3061-7003 - Fax: 5511 3062-2174

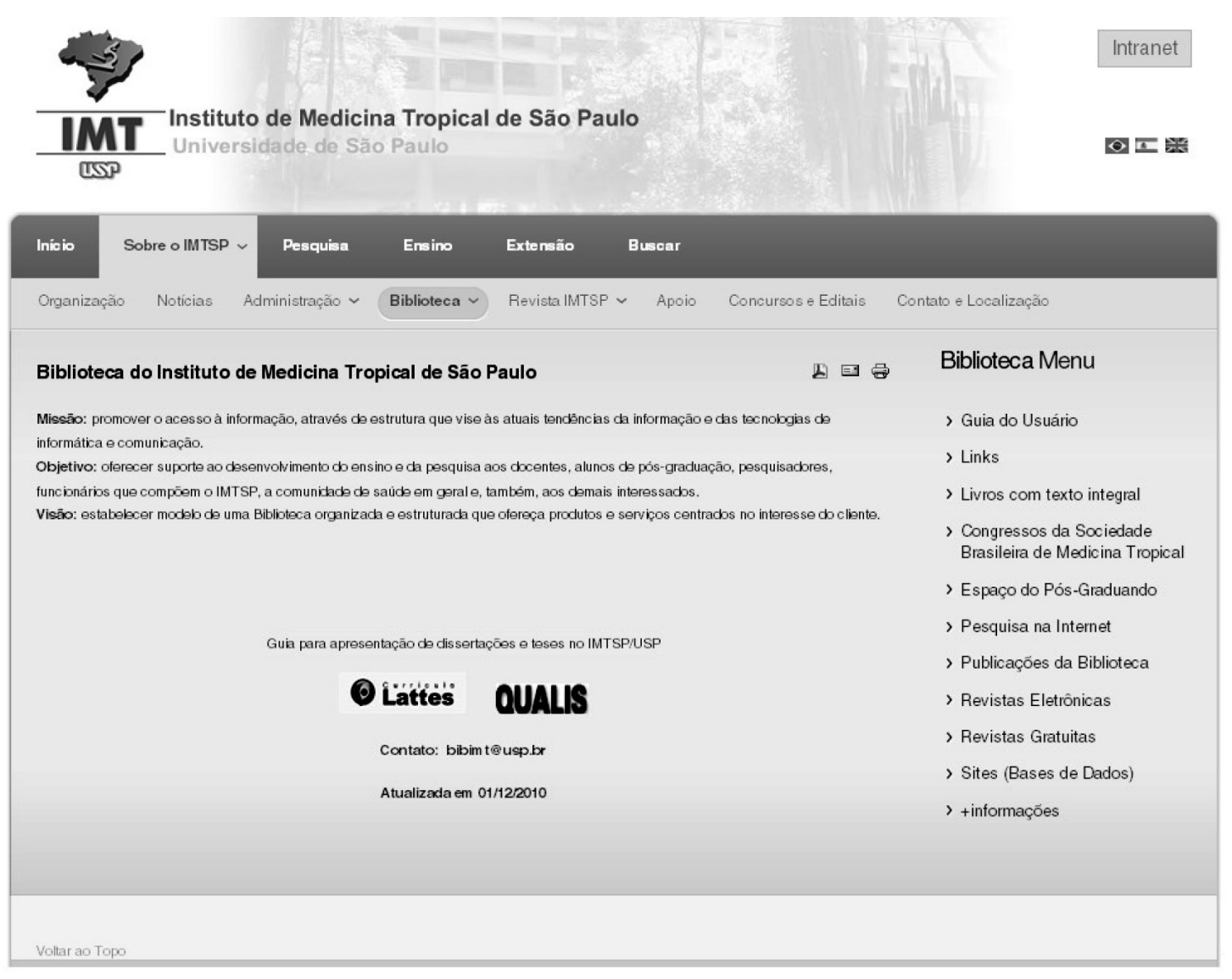

The Library of the São Paulo Institute of Tropical Medicine (IMTSP Library) was created on January 15,1959 in order to serve all those who are interested in tropical diseases. To reach this objective, we select and acquire by donation and / or exchange appropriate material to be used by researchers and we maintain interchange between Institutions thorough the Journal of the São Paulo Institute of Tropical Medicine, since the Library has no funds to build its own patrimony.

The IMTSP Library has a patrimony consisting of books, theses, annals of congresses, journals, and reference works.

The collection fo journals existing in the Library can be verified through the USP - Bibliographic Database - OPAC - DEDALUS http://dedalus.usp.br:4500/ALEPH/eng/USP/USP/DEDALUS/start of the USP network. 